\title{
In vitro antimicrobial evaluation of two indigenous functional food-plants (Chenopodium album and Solanum nigrum) used in the Oliver Reginald (O.R.) Tambo district municipality of South Africa
}

\author{
Collise Njume ${ }^{1,2 *}$, Bomkazi M. Gqaza ${ }^{3}$, Grace George $^{3}$ and Nomalungelo I. Goduka ${ }^{1}$ \\ ${ }^{1}$ Centre for Rural Development, Walter Sisulu University, Enkululekweni, Mthatha, 5117, South Africa. \\ ${ }^{2}$ Department of Medical Microbiology, Walter Sisulu University, Mthatha 5117, South Africa. \\ ${ }^{3}$ Department of Medical Biochemistry, Walter Sisulu University, Mthatha 5117, South Africa.
}

Received 17 July, 2014; Accepted 8 September, 2014

\begin{abstract}
Plants have long been the source of important products with nutritional and therapeutic properties. African indigenous functional food-plants such as Chenopodium album and Solanum nigrum may constitute important sources of phytochemical constituents for the synthesis of antimicrobial compounds against infectious organisms. The objective of this study was to determine the antimicrobial properties of $C$. album and $S$. nigrum leaves used as functional food-plants in the O.R. Tambo district municipality of South Africa. Organic and aqueous solvent-extracts of $C$. album and $S$. nigrum were tested against Staphylococcus aureus (ATCC 29213), Pseudomonas aeruginosa (ATCC 27853), Bacillus subtilis (ATCC 6051), Escherichia coli (25922) and Enterococcus faecalis (51299) using standard microbiological techniques. Ciprofloxacin was included in all the experimental runs as positive control antibiotic. The aqueous extracts of both plants were the most active with zones of inhibition diameters ranging from 0 - $20 \mathrm{~mm}$ and minimum inhibitory concentration $\left(\mathrm{MIC}_{50}\right)$ values ranging from $0.63-10 \mathrm{mg} / \mathrm{mL}$. The positive control antibiotic was highly active with zones of inhibition diameters ranging from $17-31 \mathrm{~mm}$ and $\mathrm{MIC}_{50}$ values from $0.0003-0.0005 \mathrm{mg} / \mathrm{mL}$ for all the bacteria tested. Both extracts were bactericidal with minimum bactericidal concentration (MBC) ranging from $2.5-20 \mathrm{mg} / \mathrm{mL}$. From the results, it can be concluded that both plants possess compounds with antimicrobial properties, thus validating scientifically their use in traditional medicine. However, more studies to document the respective plantprinciples responsible for antimicrobial activity of these plants would shed more light on their pharmacological properties.
\end{abstract}

Key words: Antimicrobial resistance, sensitivity tests, functional plants, Eastern Cape Province, South Africa.

\section{INTRODUCTION}

Bacterial antimicrobial resistance against commonly used antibiotics is distressingly on the rise (Falagas etal., 2013).
Patients infected with resistant bacteria are more likely to have longer, more expensive hospital stays (Matsuura

${ }^{*}$ Corresponding author. E-mail: cnjume@wsu.ac.za or njumecol@yahoo.com. Tel: +27(0)475022710 or +27(0)732481673.

Author(s) agree that this article remain permanently open access under the terms of the Creative Commons Attribution License 4.0International License 
et al., 2013). The modification of chemotherapeutic agents to limit this problem has been greatly successful. However, many reports also indicate that many of the drugs are being rendered obsolete by microbial drug-resistance (Balsalobre et al., 2014). As a result, the treatment of microbial infection is becoming increasingly complicated. Physicians have now resorted to the use of combination therapy, increasing the cost of treatment even more. Reports on Escherichia coli, Pseudomonas aeruginosa, Staphylococcus aureus, Bacillus subtilis and Enterococcus faecalis infections and antibacterial resistance reveal the need for a constant search of new drugs against these organisms (Gupta et al., 2001; Tamma et al., 2012). E. coli is a major cause of travellers' diarrhoea, one of the most common forms of diarrhoea worldwide (Mittal et al., 2009; Canizalez-Roman et al., 2013). Both $E$. coli and $P$. aeruginosa are also major causes of urinary tract infections while $S$. aureus and $E$. faecalis are common causes of nosocomial infections (Sood et al., 2008; Oli et al., 2012). B. subtilis infections are not common but few cases have been reported in the literature in patients with oesophageal perforations (Jeon et al., 2012).

The use of medicinal plants in the treatment of human infections is a common practice in many remote areas of Africa with inadequate health care facilities. Chenopodium album and Solanum nigrum are functional food-plants with wide nutritional and medicinal importance among rural communities in the O.R Tambo District Municipality of South Africa (Njume et al., 2014). They are jointly referred to as imifino ezikhulelayo in isiXhosa, meaning indigenous vegetable. $C$. album is locally known as imbikicane while S. nigrum is known as umsobo (Gqaza et al., 2013a, b). Both plants grow wildly in bushes, barren land and roadside paths from where they are harvested either for nutritional or medicinal purposes. Even though they are considered as weeds in the urban areas, many rural dwellers find them tasteful and believe in their ability to alleviate problems associated with gastrointestinal discomfort. In some parts of India, C. album is also used in ayurveda for treating anorexia, cough, dysentery, diarrhoea, oedema, piles and worm infestations (Yadav et al., 2007). Despite their medicinal uses, very little information is available in the literature on their pharmacological potential. This is surprising considering the ever-increasing rate of antimicrobial resistance of human infectious organisms to currently used drugs. The aim of this study therefore was to investigate the antimicrobial properties of these plants in an attempt to identify cheap sources of compounds for the synthesis of new drugs against medically important bacteria.

\section{MATERIALS AND METHODS}

\section{Bacterial strains}

Standard bacterial strains including Pseudomonas aeruginosa ATCC 127853, Escherichia coli ATCC 25922, Staphylococcus aureus ATCC 29213, Enterococcus faecalis ATCC 51299 and Bacillus subtilis ATCC 6051 (American Type Culture Collection, Rockville, MD) obtained from the stock culture of the National Health Laboratory Services (NHLS), Nelson Mandela Academic Hospital, Mthatha were used in this study. Ethical clearance was obtained from the Eastern Cape Department of Health and the Ethics Committee of the Faculty of Health Sciences, Walter Sisulu University (WSU). The bacteria were separately inoculated on Nutrient agar (Oxoid LIt., Basingstoke, UK) plates consisting of peptone $(5 \mathrm{~g} / \mathrm{L})$, beef extract $(3 \mathrm{~g} / \mathrm{L})$, sodium chloride $(8 \mathrm{~g} / \mathrm{L})$, agar number $2(12 \mathrm{~g} / \mathrm{L})$ at $\mathrm{pH}(7.3 \pm 0.2)$. The plates were incubated at $37^{\circ} \mathrm{C}$ for $24-48 \mathrm{~h}$ and examined for growth.

\section{Collection and preparation of plant material}

Mature plant-leaves of $C$. album and S. nigrum were harvested around the stems from home gardens and along bush paths in the vicinity of WSU main campus in Mthatha in October 2012. The plants were identified by Dr. Kathleen Immelman of the Department of Botany at WSU and voucher specimens were prepared and deposited in the Kei herbarium (CN01 and CN02). The plant-leaves were washed with tap water to remove dirt and soil particles. The plant-leaves were placed on cardboards and dried at $50^{\circ} \mathrm{C}$ for $24 \mathrm{~h}$ in a hot air oven (Heraeus, Schutzart). The plant material was powdered (ATO Mix, Cambridge) and stored in air-tight containers at $5^{\circ} \mathrm{C}$ for further analysis.

\section{Preparation of plant extracts}

Approximately $400 \mathrm{~g}$ of dried powdered plant material was exhaustively extracted in different solvents. The plant material was separately soaked in $700 \mathrm{~mL}$ of concentrated hexane, acetone, ethanol, methanol and water in $2 \mathrm{~L}$ volumetric flasks (Schott, Durban). The flasks were placed in an orbital shaker incubator (labcon, Maraisburg) for $48 \mathrm{~h}$ (Kuete et al., 2011). The plant material was centrifuged at $1006.2 \mathrm{xg}$ for $5 \mathrm{~min}$ and filtered through a fritted filter funnel of pore size $60 \AA$. The procedure was repeated twice and the three extracts combined and concentrated to dryness under vacuum (Büchi, Switzerland). The dried crude extract was collected in porcelain evaporating dish (Haldenwanger, Berlin) and left open in a biosafety class 2 cabinet (Durban, South Africa) for complete evaporation of residual solvents. The aqueous extracts were lyophilized (Castillo-Juarez et al., 2009). A 2-g sample of each extract was used for the preliminary bioassay, and where possible, another $2 \mathrm{~g}$ or more was put in universal bottles and kept in the extract bank. Stock solutions were prepared by dissolving the extracts in $80 \%$ acetone (a concentration we found to be noninhibitory to any of the bacterial strains tested).

\section{Screening of crude extracts for antibacterial activity}

The agar-well diffusion method was used for this analysis (Boyanova et al., 2005). Briefly, each bacterial suspension prepared in $0.9 \%$ saline (McFarland turbidity standard 0.5 ) was inoculated by spreading on Mueller Hinton agar (Oxoid Llt., Basingstoke, UK) plates and allowed to dry for $15 \mathrm{~min}$. Wells $(6 \mathrm{~mm}$ in diameter) were punched into the agar using a sterile stainless steel borer and filled with $70 \mu \mathrm{L}$ of the extract at $100 \mathrm{mg} / \mathrm{mL}$. Seventy microliters of $0.005 \mathrm{mg} / \mathrm{mL}$ ciprofloxacin and $80 \%$ acetone were included in all experiments as positive and negative controls, respectively. The plates were incubated at $37^{\circ} \mathrm{C}$ for $24 \mathrm{~h}$, after which the diameters of zones of inhibition were measured in $\mathrm{mm}$. The experiment was repeated twice, and means for zones were recorded. 
Table 1. Antimicrobial activity of crude extracts of S. nigrum and C. album as revealed by the agar-well diffusion technique.

\begin{tabular}{|c|c|c|c|c|c|c|c|c|c|c|c|}
\hline \multirow{2}{*}{ Bacteria } & \multicolumn{5}{|c|}{ S. nigrum } & \multicolumn{6}{|c|}{ C. album } \\
\hline & $\mathbf{H}$ & A & $E$ & $M$ & $\mathbf{w}$ & $\mathbf{H}$ & $A$ & $\mathrm{E}$ & $M$ & $\mathbf{w}$ & CIP \\
\hline & 15 & 0 & 10 & 0 & 17 & 0 & 13 & 0 & 0 & 14 & 22 \\
\hline \multirow[t]{3}{*}{ Bs } & 11 & 10 & 10 & 0 & 20 & 0 & 21 & 0 & 0 & 17 & 29 \\
\hline & 10 & 0 & 12 & 0 & 15 & 0 & 11 & 0 & 0 & 17 & 31 \\
\hline & 0 & 0 & 10 & 0 & 10 & 0 & 0 & 0 & 0 & 11 & 19 \\
\hline \multirow[t]{3}{*}{ Sa } & 7 & 0 & 10 & 0 & 12 & 0 & 0 & 0 & 0 & 10 & 19 \\
\hline & 9 & 0 & 9 & 0 & 14 & 0 & 10 & 9 & 0 & 10 & 17 \\
\hline & 0 & 0 & 11 & 0 & 0 & 0 & 0 & 0 & 0 & 17 & 21 \\
\hline \multirow[t]{3}{*}{ Ef } & 0 & 0 & 15 & 0 & 0 & 0 & 0 & 0 & 0 & 14 & 19 \\
\hline & 0 & 0 & 11 & 0 & 0 & 0 & 11 & 0 & 0 & 14 & 21 \\
\hline & 9 & 0 & 9 & 0 & 11 & 0 & 10 & 9 & 0 & 9 & 21 \\
\hline \multirow[t]{3}{*}{ Ec } & 0 & 0 & 10 & 0 & 10 & 0 & 0 & 0 & 0 & 10 & 18 \\
\hline & 0 & 11 & 13 & 0 & 10 & 0 & 10 & 0 & 0 & 9 & 18 \\
\hline & 0 & 0 & 10 & 0 & 13 & 0 & 0 & 0 & 0 & 15 & 19 \\
\hline \multirow[t]{2}{*}{$\mathrm{Pa}$} & 0 & 0 & 13 & 0 & 12 & 0 & 0 & 10 & 0 & 17 & 27 \\
\hline & 0 & 0 & 9 & 0 & 10 & 0 & 0 & 0 & 0 & 16 & 23 \\
\hline Mean \pm SD & $4.1 \pm 5.4$ & $1.4 \pm 3.6$ & $10.8 \pm 1.7$ & 0 & $10.3 \pm 6.0$ & 0 & $5.7 \pm 6.8$ & $1.8 \pm 3.8$ & 0 & $13.3 \pm 3.1$ & $21.6 \pm 4.2$ \\
\hline
\end{tabular}

Last row data are mean \pm SD of 15 determinations for each plant crude extract; $H$, hexane; $A$, acetone; $E$, ethanol; $M$, methanol; $W$, water; bacteria; Bs, Bacillus subtilis; Sa, Staphylococcus aureus; Ef, Enterococcus faecalis; Ec, Escherichia coli; Pa, Pseudomonas aeruginosa.

\section{Determination of minimum inhibitory concentration $\mathbf{( 5 0 \%}$ susceptibility)}

Based on their good antimicrobial activity in the screening, the aqueous extracts were selected for determination of minimum inhibitory concentration $\left(\mathrm{MIC}_{50}\right)$ using the micro broth dilution technique performed in 96-well plates (Bonacorsi et al., 2009). Two-fold dilutions of the extract and control antibiotic (ciprofloxacin) were prepared in the wells containing Mueller Hinton broth. The final extract concentration ranged from $20-0.31 \mathrm{mg} / \mathrm{mL}$ while that of the control antibiotic ranged from $0.005-0.00015 \mathrm{mg} / \mathrm{mL}$. Exactly $20 \mu \mathrm{L}$ of an 18-h old broth culture (McFarland turbidity standard 0.5 ) of the bacteria was inoculated into $180 \mu \mathrm{L}$ of extract-containing culture medium. Negative control wells were prepared with culture medium only and bacteria suspension and broth only respectively. An automatic ELISA micro plate reader (Tokyo, Japan) adjusted to 590 $\mathrm{nm}$ was used to measure the absorbance of the plates before and after 24-h incubation. The absorbancies were compared to detect an increase or decrease in bacterial growth and the values plotted against concentration. The lowest concentration of the test extract resulting in inhibition of $50 \%$ of bacterial growth was recorded as the MIC.

\section{Determination of minimum bactericidal concentration (MBC)}

The MBC was determined following well established procedures (Nethathe and Ndip, 2011). Briefly, the entire content of the MIC well $(\approx 200 \mu \mathrm{L})$ was serially ten-fold diluted in $0.9 \%$ saline. A loopfull was taken from each tube and inoculated into Mueller Hinton agar plates and incubated for $24 \mathrm{~h}$ at $37^{\circ} \mathrm{C}$. The $\mathrm{MBC}$ was recorded as the lowest concentration of the extract or antibiotic that gave complete inhibition of colony formation of the test bacteria at the later cultivation.

\section{Statistical analysis}

The statistical package used for analysis was SPSS v18.0 (SPSS
Inc., Chicago, IL). One-way analysis of variance (ANOVA) was used to compare the mean difference in inhibitory activities of extracts and control antibiotic, followed by Turkey's post-hoc test. Differences were considered significant at $P<0.05$.

\section{RESULTS}

The zones of inhibition diameters of active plant extracts ranged from $0-20 \mathrm{~mm}$ while those for the control antibiotic ranged from $17-31 \mathrm{~mm}$. Hexane extracts of $C$. album and methanol extracts of both plants were inactive (Table 1).

Based on agar-well results, the most active extracts (aqueous) were selected for MIC and MBC determination alongside the positive control antibiotic. The activity of the aqueous extracts was confirmed with $\mathrm{MIC}_{50}$ values of $0.63-10$ and $0.63-7.5 \mathrm{mg} / \mathrm{mL}$ for $S$. nigrum and $C$. album, respectively (Table 2). Both extracts were also bactericidal against the tested bacteria with MBC values ranging from 2.5 and $5.0-20 \mathrm{mg} / \mathrm{mL}$ for $C$. album and $S$. nigrum, respectively (Table 2). MIC and MBC values of 0.0003 and $0.001 \mathrm{mg} / \mathrm{mL}$ respectively were recorded for the control antibiotic and were the least values in the entire study.

\section{DISCUSSION}

There could be a double advantage in the recognition of functional food-plants as useful resources in the maintenance of good health in South Africa. Previous 
Table 2. Minimum Inhibitory and bactericidal concentration $(\mathrm{mg} / \mathrm{mL})$ values of plant crude extracts and control antibiotic tested against medically important bacteria.

\begin{tabular}{lccc}
\hline Bacteria species & S. nigrum & C. album & Ciprofloxacin \\
\hline MIC & & & \\
B. subtilis & 2.5 & 0.63 & 0.0005 \\
S. aureus & 0.63 & 0.63 & 0.0003 \\
E. faecalis & 2.5 & 1.3 & 0.0005 \\
E. coli & 5 & 7.5 & 0.0005 \\
P. aeruginosa & 10 & 5 & 0.0003 \\
Total & $4.1 \pm 3.6$ & $3.0 \pm 3.1$ & $0.0004 \pm 0.0001$ \\
& & & \\
MBC & & & \\
B. subtilis & 5 & 2.5 & 0.001 \\
S. aureus & 10 & 2.5 & 0.001 \\
E. faecalis & 20 & 10 & 0.002 \\
E. coli & 10 & 20 & 0.003 \\
P. aeruginosa & 10 & 10 & 0.002 \\
Total & $11 \pm 5.5$ & $9 \pm 7.2$ & $0.002 \pm 0.0008$ \\
\hline
\end{tabular}

The total results shown are representative of mean \pm SD value of five determinations for each plant crude extract or control antibiotic.

studies on some of these plants indicate them to be useful sources of important dietary components such as vitamins (A, B2, C, folic acid), iron, selenium, zinc, calcium and magnesium (Akubugwo et al., 2007; van der Walt et al., 2008; Gqaza et al., 2013a,b). Some of these nutrients occur in high enough quantities to meet the recommended daily allowance in children, preventing hidden hunger, its effects (stunted growth, anaemia, overweight, obesity) and promoting optimal growth and development (van Jaarsveld et al., 2014). Their medicinal properties indicate that they may also constitute an important source of antioxidants and therapeutic compounds against human infectious organisms. Many plants have been reported to contain flavonoids, alkaloids, tannins, phenols, saponins or other secondary metabolites which serve as defense mechanisms against microorganisms, insects and animals (Madduluri et al., 2013). These compounds are known to act in different ways to exert antimicrobial action. Some, such as tannins do so by binding to proline-rich proteins and interfering with protein synthesis while others such as saponins interact with bacterial cell walls to cause leakage of vital cell proteins (Shimada et al., 2006; Madduluri et al., 2013). However, this study did not evaluate the mechanism of action of the crude extracts against the tested bacteria. Nevertheless, it indicates that crude extracts of $C$. album and S. nigrum, especially aqueous extracts have the potential for further evaluation as antibacterial agents. The crude extracts inhibited the test bacteria, sometimes at low concentrations of $0.63 \mathrm{mg} / \mathrm{mL}$. However, higher concentrations, at times up to $20 \mathrm{mg} / \mathrm{mL}$ were needed to completely kill the bacteria (Table 2).
Gram-positive organisms: S. aureus, E. faecalis and $B$. subtilis were the most susceptible in the entire study while Gram-negative bacteria such as $E$. coli and $P$. aeruginosa were less susceptible (Tables 1 and 2). The difference in susceptibility between Gram-negative and positive bacteria to antimicrobial agents has been reported by other researchers (Cock, 2007; Madduluri et al., 2013) and may be attributed to structural differences in the cell wall of both organisms. Gram-negative bacteria have a lipid protective sheath around their cell walls which seems to shield them from the effects of antimicrobial agents (Silhavy et al., 2010). All the bacteria tested were highly susceptible to ciprofloxacin, the control antibiotic (Tables 1 and 2). The plant crude extracts were relatively less active when compared to ciprofloxacin $(P<0.05)$. This was expected as the control antibiotic is a purified compound which may also contain excipients to facilitate activity. The crude extracts on the other hand are made of numerous compounds; some of which may be synergistic or antagonistic against each other. Equally important is the fact that the quantity of the active ingredient in the crude extracts may be in minute quantities, not enough to exhibit the type of activity demonstrated by the control antibiotic. Of all the bacteria tested, $B$. subtilis and $S$. aureus were most susceptible to aqueous extracts of the plants, producing large zones of inhibition diameters (Table 1), low MIC and MBC values (Table 2). However, there were no significant differences in antibacterial activity between the aqueous extracts of $C$. album and $S$. nigrum $(P>0.05)$.

\section{Conclusion}

The current study illustrates the antibacterial properties of crude extracts of $C$. album and $S$. nigrum against some selected bacteria of medical importance. The study shows that aqueous extracts of both plants are inhibitory and bactericidal to $S$. aureus, $B$. subtilis, $P$. aeruginosa, $E$. coli and $E$. faecalis. These findings are consistent with their folkloric use in the treatment of stomach-related morbidities in the O.R. Tambo District Municipality of South Africa. However, more studies to document the plants active ingredients will shed more light on their pharmacological relevance as antibacterial agents.

\section{Conflict of interest}

The author(s) have not declared any conflict of interests.

\section{ACKNOWLEDGEMENTS}

The authors are grateful to the Department of Science and Technology (DST) and the National Research Foundation (NRF), South Africa for funding this study through a grant awarded to the Research Chair for 
Indigenous Knowledge System at Walter Sisulu University, South Africa.

\section{REFERENCES}

Akubugwo IE, Obasi AN, Ginika SC (2007). Nutritional potential of theleaves and seeds of blacknightshade-Solanumnigrum $\mathrm{L}$. varvirginicum from Afikpo-Nigeria. Pak. J. Nutr. 6:323-326.

Balsalobre LC, Dropa M, Matte MH (2014). Anoverview of Antimicrobial resistance and its public health significance. Braz. J. Microbiol. 45(1):1-5.

Bonacorsi C, Raddi MSG, Iracilda ZC, Sannomiya M, Vilegas W (2009). Anti-Helicobacter pylori activity and immunostimulatory effect of extracts from ByrsonimacrassaNied. (Malpighiaceae). Complement. Altern. Med. 9:1472-6882.

Boyanova L, Gergova G, Nikolov R, Derejian S, Lazarova E, Katsarov $\mathrm{N}$, Mitov I, Krastev Z (2005). Activity of Bulgarian propolis against 94 Helicobacter pylori strains in vitro by agar-well diffusion, agar dilution and disc diffusion methods. J. Med. Microbiol. 54: 481-483.

Canizalez-Roman A, Gonzalez-Nunez E, Vidal JE, Flores-Villasenor H, Leon-Sicairos N (2013). Prevalence and antibiotic resistant profiles of diarrheagenic Escherichia coli strains isolated from food items in North Western Mexico. Int. J. Food. Microbiol. 164(1):36-45.

Castillo-Juárez I, González V, Aime-Aguilar H, Martínez G, Linares E, Bye R, Romero I (2009). Anti-Helicobacter pylori activity of plants used in Mexican traditional medicine for gastrointestinal disorders. J. Ethnopharmacol. 122(2):402-405.

Cock I (2007). Antibacterial activity of selected Australian native plant extracts. Int. J. Microbiol. 4(2):76-81.

Falagas ME, Karageorgopoulos DE, Leptidis J, Korbila IP (2013). MRSA in Africa: Filing the global map of antimicrobial resistance. PLoS One 8(7) e68024:1-12.

Gqaza BM, Njume C, Goduka NI, George G (2013a). Nutritional assessment of Chenopodium album L. (Imbikicane) young shoots and mature plant-leaves consumed in the Eastern Cape Province of South Africa. Int. Conf. Nutr. Food Sci. DOI: 10.7763/IPCBEE.

Gqaza MB, Njume C, Goduka IN, Grace G (2013b). The proximate composition of S. nigrum plant-leaves consumed in the Eastern Cape Province of South Africa. Int. Conf. Nutr. Food Sci. DOI: 10.7763/IPCBEE.

Gupta K, Hooton TM, Stamm WE (2001).Increasing antimicrobial resistance and the management of uncomplicated communityacquired urinary tract infections. Ann. Int. Med. 135(1):45-50.

Jeon YL, Yang JJ, Kim MJ, Lim G, Cho SY, Park TS, Suh JT, Park YH, Lee MS, Kim SC, Lee HJ (2012). Combined Bacillus licheniformis and Bacillus subtilis infection in a patient with oesophageal perforation. J. Med. Microbiol. 61(12):1766-1769.

Kuete V, Ango PY, Fotso GW, Kapche GD, Dzoyem JP, Wouking AG, Ngadjui BT, Abegaz BM (2011). Antimicrobial activities of the methanol extract and compounds from Artocarpus communis (Moraceae). BMC Complement. Altern. Med. 11(42):1-5.
Madduluri S, Rao KB, Sitaram B (2013). In vitro evaluation of antibacterial activity of five indigenous plants extracts against five bacteria pathogens of humans. Int. J. Pharm. Pharm. Sci. 5(4):679684.

Matsuura GT, Pharm D, Barg N (2013). Update on the antimicrobial management of foot infections in patients with diabetes. Clin. Diabetes 31(2):59-65.

Mittal R, Aggarwal S, Sharma S, Chhibber S, Harjai K (2009). Urinary tract infections caused by Pseudomonas aeruginosa: a minireview. J. Infect. Public Health 2:101-111.

Nethathe BB, Ndip RN (2011). Bioactivity of Hydnora africana on selected bacteria pathogens: Preliminary phytochemical screening. Afr. J. Microbiol. Res. 5(18):2820-2826.

Njume C, Goduka NI, George G (2014) Indigenous leafy vegetables (imifino, morogo, muhuro) in South Africa: a rich and unexplored source of nutrients and antioxidants. Afr. J. Biotechnol. 13(19):19331942.

Oli AK, Sungar R, Shivshetty N, Hosamani R, Rivansiddappa KC (2012). A study of scanning electron microscopy of vancomycin resistant Enterococcus faecalis from clinical isolates. Adv. Microbiol. 2:93-97.

Shimada T (2006). Salivary proteins as a defense against dietary tannins. J. Chem. Ecol. 32(6):1149-1163.

Silhavy TJ, Kahne D, Walker S (2010). The bacterial cell envelope. Cold Spring Harb. Perspect. Biol. 2(5):1-17.

Sood S, Malhotra M, Das BK, Kapil A (2008). Enterococcal infections and antimicrobial resistance. Indian J. Med. Res. 128:111-121.

Tamma PD, Cosgrove SE, Maragakis LL (2012). Combination therapy for treatment of infections with gram negative bacteria. Clin Microbiol. Rev. 25(3):450-470.

van der Walt AM, Ibrahim MI, Benzuidenhout CC, Loots DT (2008). Linolenic acid and folate in wild-growing African dark leafy vegetables (Morogo). Public Health Nutr. 12:525-530.

van Jaarsveld P, Faber M, van Heerden I, Wenhold F, van Rensburg WJ, van Averbeke W (2014). Nutrient content of eight African leafy vegetables and their potential contribution to dietary reference intakes. J. Food Compost. Anal. 33:77-84.

Yadav N, Vasudeva N, Singh S, Sharma SK (2007). Medicinal properties of genus Chenopodium Linn. Nat. Prod. Rad. 6(2):131134. 